\title{
IDENTIFIKASI KEANEKARAGAMAN DAN POLA PENYEBARAN MAKROALGA DI DAERAH PASANG SURUT PANTAI PIDAKAN KABUPATEN PACITAN SEBAGAI SUMBER BELAJAR BIOLOGI
}

\author{
Ilham Budi Setyawan ${ }^{1}$, Wahyu Prihanta ${ }^{1}$, dan Elly Purwanti ${ }^{1}$ \\ ${ }^{1}$ Program Studi Pendidikan Biologi, FKIP, Universitas Muhammadiyah Malang \\ e-mail: marovisepuxanir@gmail.com
}

\begin{abstract}
This research aimed to find out variance, ecology parameter,variance index, and dispersion pattern of macroalgae existed in intertidal pidakan beach sub-district Pacitan Residence.The results of research in the area of tidal beach Pidakan on 90 plots was found in 1925 with 17 individual macro algae species originating from the third division Rhodophyta, Chlorophyta and Phaeophyta.Variance index of ( $H^{\prime}$ ) was high richness category and value (E) was means community tend to flat. Index of Morisita (IM) mean dispersion of all Macroalgae was clumped. As a complement to the results of the study are used as a learning module macroalgae for SMA/MA.
\end{abstract}

Keywords: identification, diversity, macroalgae, beach, Pacitan

Pacitan merupakan daerah dengan kawasan pantai yang begitu luas, Kabupaten Pacitan bukan hanya menarik untuk berwisata namun juga cocok untuk lokasi perlindungan biota laut. Kabupaten Pacitan terletak di Provinsi Jawa Timur di bagian selatan ujung barat daya. Kab. Pacitan terletak di antara $110^{\circ} 55^{\prime}-111^{\circ} 25^{\prime}$ Bujur Timur dan $7^{\circ} 55^{\prime}-8^{\circ} 17^{\prime}$ Lintang Selatan, dengan luas wilayah $1.389,8716 \mathrm{Km}^{2}$ atau 138.987,16 Ha. Luas tersebut sebagian besar berupa perbukitan yaitu kurang lebih $85 \%$, gunung-gunung kecil lebih kurang 300 buah menyebar diseluruh wilayah Kabupaten Pacitan, sedang selebihnya merupakan dataran rendah berupa kawasan pantai. Wilayahnya berbatasan dengan Kab. Ponorogo di utara, Kab. Trenggalek di timur, Samudra Hindia di selatan, serta Kab. Wonogiri (Jawa Tengah) di barat (Pacitankab, 2007).

Perairan Pantai masih sangat ideal untuk penelitian, karena jauh sumber pencemaran dan pemukiman penduduk. Penelitian Makroalga selama ini hanya terbatas pada parameter ekologis, kepadatan dan dominasi Makroalga di beberapa pesisir pantai. Menurut Allison (2004) bahwa topik yang sama banyak dilakukan di daerah subtropik (Kadi A.,2009). Penelitian keragaman, kepadatan dan pola penyabaran Makroalga ini masih jarang dilakukan di pantai Pidakan Kabupaten Pacitan. Hal ini pula yang menjadi pertimbangan untuk melengkapi data Makroalga tentang keragaman, kepadatan dan pola penyebaran yang dilakukan di perairan dalam kondisi biofisik yang berbeda. Di Indonesia data Keragaman, kepadatan Makroalga belum terpola di beberapa perairan Pulau kecil maupun besar, karena kehadiran Makroalga di beberapa perairan masih banyak yang belum teridentifikasi.

Pantai Pidakan Kabupaten Pacitan yang kondisi pantainya berupa pantai yang berkarang dan berpasir serta letaknya jauh dari perkampungan merupakan habitat yang cocok bagi pertumbuhan Makroalga. Disamping untuk tujuan wisata, banyak masyarakat sekitar pantai yaitu Dusun Godek Kulon, Desa Jetak, Kec. Tulakan yang terletak dekat pantai Pidakan, bermata pencaharian dengan memanfaatkan kekayaan laut, namun mereka tidak banyak mengetahui keberadaan dan pemanfaatan Makroalga. 
Sumber belajar adalah semua jenis sumber yang ada di sekitar kita yang memungkinkan kemudahan terjadinya proses belajar (Asyhar,2012). Penggunaan lingkungan sebagai sumber belajar tidak banyak mengalami kesulitan, mengingat biologi adalah ilmu yang mempelajari tentang makhluk hidup yang obyek dan persoalannya banyak terjadi di lingkungan alam sekitar (Afriyani,2005).

Tumbuhan tingkat rendah yaitu Makroalga diajarkan di sekolah mulai tingkat Sekolah Menegah Pertama sampai perguruan tinggi pada jurusan tertentu terutama jurusan biologi. Di Sekolah Menengah Atas pengajaran Makroalga atau biasa disebut Protista mirip tumbuhan berdasarkan lampiran Permendikbud No.59 tahun 2013 tentang Kurikulum SMA-MA, tercantum dalam Kompetensi Dasar : 3.5 Menerapkan prinsip klasifikasi untuk menggolongkan protista berdasarkan ciri umum kelas dan peranannya dalam kehidupan melalui pengamatan secara teliti dan 4.5 Merencanakan dan melaksanakan pengamatan tentang ciri-ciri dan peranan Protista dalam kehidupan dan menyajikan hasil pengamatan dalam bentuk model/chart/gambar.

Adanya pembaruan kurikulum tersebut diharapkan sekolah mampu mengoptimalkan sumber daya yang ada, baik sumber daya alam, sumber daya manusia dan sumber belajar sehingga dapat mewujudkan tujuan pendidikan secara optimal. Penggunaan alam sekitar sebagai sumber belajar sangatlah tepat dalam kurikulim 2013 masa kini. Obyek serta persoalan-persoalan biologi banyak ditemukan disekitar kita, seperti pemanfaatan Makroalga hal ini sangatlah baik bila dijadikan sebagai sumber belajar khususnya pada pendidikan yang berdekatan dengan kawasan pantai dan laut. Berdasarkan hal tersebut maka pengenalan obyek biologi berupa Makroalga secara langsung melalui sumber belajar pada siswa menjadi sebuah keharusan dalam pembelajaran biologi. Menurut Afriyani (2005), banyak yang dapat dikaji dari lingkungan, dimana lingkungan merupakan laboratorium alam yang mempunyai peranan sangat penting bagi anak didik sebagai sumber belajar.

Sumber pembelajaran yang digunakan guru hendaknya inovatif dengan sajian yang menarik minat peserta didik untuk mempelajari materi di dalamnya. Sumber belajar bisa berupa media cetak yang meliputi : buku ajar, modul, majalah ilmiah, handout, work book (Arief, 2006). Handout merupakan bahan ajar yang dituangkan secara ringkas yang berguna sebagai pegangan dalam pembelajaran. Dengan adanya handout guru membantu peserta didik dalam mengikuti pembelajaran secara lebih terarah dan terfokus, karena handout adalah sejenis kisi-kisi materi ajar yang akan disampaikan guru. Terkait dengan pembuatan Handout yang inovatif, salah satu alternatifnya bisa dicantumkan beberapa gambar yang mengarah pada materi ajar.

Beradasarkan uraian di atas dan mengigat bahwa Makroalga sangat berperan penting bagi ekosistem perairan, serta pada saat ini penelitian tentang Makroalga di kawasan pantai wisata Pidakan masih belum dilakukan maka perlu dilakukan penelitian sehingga nantinya diharapkan dapat memberikan gambaran sebagian kekayaan Makroalga di pantai Pidakan serta pemanfaatanya sebagai sumber dan media belajar biologi di sekolah.

\section{METODOLOGI PENELITIAN}

\section{Tempat dan Waktu Penelitian}

Penelitian ini akan dilakukan satu tempat, di daerah pasang surut Pantai Pidakan Kabupaten Pacitan dan untuk pemanfaatan Makroalga sebagai sumber belajar berupa handout akan dilakukan validasi handout kepada guru mata pelajaran biologi SMA/MA. Penelitian dilakukan pada bulan Mei - Juni 2014 pada 
saat air surut siang hari antara jam 14.0017.00 WIB.

\section{Metode Penelitian}

1. Kondisi Lokasi Penelitian

Data abiotik yang diamati adalah suhu air laut, $\mathrm{pH}$, Salinitas, Intensitas Cahaya dan Jenis Substrat. Pengukuran data abiotik tersebut dilakukan pada saat penelitian di siang hari pada setiap stasiun. Lokasi pengukuran jarak antar stasiun $350 \mathrm{~m}$ dengan memperhatikan garis surut pantai terendah dan garis pasang tertinggi yaitu $100 \mathrm{~m}$.

2. Penetapan Lokasi Sampel

Pada lokasi penelitian dibuat 5 stasiun dalam 1 stasiun terdiri dari 3 garis transek kuadrat. Setiap transek kuadrat terdiri 6 plot. Tiap plot berukuran $2 \times 2 \mathrm{~m}^{2}$, jarak antar plot masing-masing $10 \mathrm{~m}$, dengan jarak antar transek $25 \mathrm{~m}$. Sampel dalam penelitian total semua spesises makroalga yang ditemukan di 90 plot dalam 15 transek

3. Pengumpulan Data

Pada setiap plot dihitung jumlah spesies makroalga yang ditemukan serta kepadatan, frekuensi, luas penutupan, indeks nilai penting ,indeks keanekaragaman dan Pola penyebaran. Identifikasi jenis di lapangan dengan menggunakan bukubuku identifikasi diantaranya Setchell \& Gardener (1920 \& 1925), Gifford (1853), Harvey (1845) dan Sulistijo (2009) serta sumber literatur yang kredibel. Identifikasi Makroalga dapat dilakukan dengan pengenalan atau pencandraan karakter morfologi seperti bentuk \& ukuran tubuh, variasi warna, serta bentuk thallus \& lembaga
4. Penyajian Data Sebagai Sumber Belajar

Data disajikan berupa Inventarisasi Makroalga dan contoh handout sebagai sumber pembelajaran. Makroalga yang ditemukan dimanfaatkan untuk bahan pembuatan handout sebagai sumber belajar. Struktur handout dapat bervariasi, tergantung pada karakter materi yang akan disajikan. Secara umum unsur penyusunan Handout adalah : Standart Kompetensi, Kompetensi Dasar , Ringkasan materi, Informasi pendukung, Latihan soal-soal. Untuk mengtahui kualitas hanout dilakukan uji kelayakan dengan menggunakan metode pembagian angket pada guru di salah satu SMA/MA.

\section{HASIL}

Penelitan ini menemukan 15 spesies alga makro yang tersebar pada 90 plot dan 15 transek. Secara umum dapat dideskripsikan sebagai berikut :

\section{Ulva lactuca L.}

Thallus lembaran tipis, kadangkadang kelihatan trasparan. Warna thallus hijau terang hingga gelap. Alga ini melekat dengan menggunakan alat perekat berbentuk cakram pada batuan atau lain tangkainya pendek terhubung dengan daun yang tipis. Tebalnya 0,1 mm bentuk dan ukuranya tidak teratur (Setchel \& Gardener, 1920 ; 265). Tumbuh melekat pada substrat karang mati di daerah paparan terumbu karang di perairan dangkal dengan kedalaman 0,5-5 $\mathrm{m}$ dan dapat hidup pada perairan payau. Sebarannya agak luas di perairan pantai dangkal di seluruh Indonesia (Atmadja,1996)

2. Entermorpha intetnalis (Linnaeus) Link 
Thallus panjang dan ramping, diameter seragam; biasanya mengambang

tidak terikat. thalus sederhana atau memiliki beberapa cabang mirip dengan

thalus utama; panjang yang bervariasi dari beberapa sentimeter hingga beberapa meter; diameter $1-10 \mathrm{~cm}$. Stipe pertama melekat berbentuk silinder pendek, tetapi sering terpisah dan mengambang; silinder mengalami perluasan pada bagian atas, sering banyak lekukan dan berkerut, dan tidak teratur dan sering menyempit (Setchel \& Gardener 1920 : 252-253).

3. Caulerpa racemosa (Forsskal) J.Agardh

Tanaman ini telah mendirikan cabang yang timbul dari stolon horisontal melekat pada sedimen pada interval dengan turun rimpang. Cabang-cabang tegak timbul setiap beberapa sentimeter, mencapai sebanyak $30 \mathrm{~cm}$. Sejumlah besar branchlets, menyerupai tubuh oval atau bulat pada batang, muncul dari masing-masing cabang tegak. Dimana cabang dan stolons dekat bersamasama, branchlets membentuk tikar padat struktur yang tampaknya bola. Tanaman yang coenocytic, yaitu, tanaman ini multinucleate dan nonseptate. Alga ini disebut juga "Sea grapes" Anggur Laut. Habitat banyak terjadi dari teluk dangkal berlumpur untuk membersihkan lingkungan terumbu air, pada kedalaman dari dekat permukaan hingga $100 \mathrm{~m}$. Hal ini dapat terjadi berdekatan dengan karang hidup seperti tumbuh di karang Acropora palmata (Sulistijo,2009)

4. Valoni aegagropila C. Agardh
Thallus tersusun berkilau, kuat, bulat bergelembung dari bentuk pentungan atau tak teratur (panjang 3$10 \mathrm{~mm}$ dan diameter 2-3 $\mathrm{mm}$ ); menempel satu sama lain oleh zat perekat; berair banyak, beberapa ukuran (lebar 1-10 cm atau lebih). Hijau gelap sampai hijau coklat. Tumbuh di batu atau pecahan karang di prairan dangkal (Coremap,2007.)

5. Gracilaria gracilis (Stackhouse) M. Steentoft

Thallus tegak, hingga $20 \mathrm{~cm}(<1 \mathrm{~m}$ kedalaman) atau $100 \mathrm{~cm}(>$ kedalaman $1 \mathrm{~m})$ panjang, berlabuh di sedimen, tidak ada pegangan erat. Berulangulang dan tidak teratur bercabang, hingga empat order. Cabang silinder, hingga $2 \mathrm{~mm}$ lebar, sering tercekat di dasar (diameter $0.8 \mathrm{~mm}$ ); apices lancip ke titik akut. Spesimen segar tulang rawan, merah tua sampai ungu. Habitat pada batuan, umumnya didistribusikan di daerah intertidal dan subtidal, terutama di pantai berpasir (lyer,2004).

6. Gelidium amansii J.V. Lamouroux

Bagian- bagian tubuh dari gelidium amansii yaitu memiliki holdfast sebagai tempat melekat di karang, blades atau thallus pipih yang berbentuk seperti daun yang dipinggirnya rintik-rintik berdekatan menyerupai daun seledri. Memiliki talus agak keras, silindris atau agak pipih, bercabang-cabang menyirip tersusun menggerombol serta berhimpitan. Alga ini tumbuh baik pada daerah eulittoral dan sublittoral. (McHugh, 2003). Habitat dan sebaran Gelidium di Indonesia pada umumnya di perairan pantai berbatu dan terbuka yang kebanyakan di daerah pantai 
Samudera India (Kadi \& Atmadja 1988).

7. Euchema edule Weber van Bosse

Thallus silindris, permukaan licin, gelatinaeus-cartilaginaeus, warna hijau-kuning atau coklat-hijau. Percabangan berselang seling dengan interval yang jarang. Pada Thallus terdapat benjolan-benjolan yang sebagian berkembang menjadi duriduri besar. Ukuran thallus umumnya lebih besar dari pada jenis Eucheuma lainnya, sehingga rumpun tampak lebih kokoh tetapi tidak begitu rimbun. Tempat tumbuh umumnya pada daerah-daerah yang selalu terkena gerakan air, di bagian ujung luar terumbu, melekat pada batu. Terdapat turnbuh di perairan Bali dan Lombok (Harvey,1853).

8. Euchema cottoni Webber van Bosse

Eucheuma cottonii bentuk thallus silindris, berduri-duri, duri tidak teratur dan tidak melingkari thallus. Duri-duri runcing memanjang dan agak jarang. Permukaan thallus licin, sifat substansinya cartilagineous, penampakan thalli bervariasi mulai dari sederhana sampai kompleks.

Warna thallus : hijau, hijau kekuningan, abu-abu atau merah. Percabangan ke berbagai arah dengan batang-batang utama keluar saling berdekatan di daerah basal (pangkal). Habitat : tumbuh melekat ke substrat dengan alat pelekat berupa cakram (holdfast). Cabang pertama dan kedua tumbuh membentuk rumpun yang rimbun dengan ciri-ciri khusus, mengarah ke arah datangnya sinar matahari (Gifford, 1853; Harvey,1845).

9. Codium edule P.C. Silva
Thallus seperti tanaman berwarna hijau tua, diameter $1-2 \mathrm{~cm}$. Lembut, seperti spon untuk disentuh. Cabang dikotomis dibagi atas tiga bagian yang silinder dan meruncing ke ujung, 3-5 $\mathrm{mm}$, dan melekat satu sama lain atau ke substrat, bantalan seperti struktur rhizoid. Cabang-cabang di bawah talus yang selalu melengkung. Cabang berbaring bersujud dan melekat pada suatu substrat. Habitat: Codium edule umum di seluruh pulau dan ditemukan intertidal untuk subtidal, 2-4 m dalam, tetapi paling sering subtidal.. Dapat diketemukan antara lain di daerah perairan pantai selatan Jawa (Gifford,1853; Coremap,2007)

\section{Jania longifurca Zanardini}

Tanaman membentuk lebar, struktur dichotomously bercabang, tumbuh di kusut, gumpalan kecil. Cabang terdiri dari kaku, berbatu, ruas silinder dengan sambungan fleksibel. Ruas cahaya merah untuk berwarna merah muda; sambungan putih. habitat: Umumnya menghuni terlindung, agak berbayang daerah karang, sering di celah-celah (Coremap,2007).

11. Jania rubens (Linnaeus) Lamouroux

Thallus ramping, berwarna seperti mawar, artikulasi, Fronds mengalami pengapuran, dalam tandan yang dibulatkan dengan tinggi $50 \mathrm{~mm}$. Berulang kali dikotomus bercabang, spesimen yang lebat secara sekunder dan menyirip. Segmen silinder, diamater 100 um., Cabang-cabang bantalan sedikit pipih berdiameter 200 um. Melekat dengan cakram berbentuk kerucut kecil, tetapi menyebar secara vegetatif dengan mengembangkan cakram dari cabangnya sebagai alat melekat 
dengan substrat padat. Habitat: epifit, hanya ditemukan tumbuh epiphytically pada tanaman yang lebih tua dari ganggang coklat dan berada di pangkal, tumbuh baik daerah di intertidal, selatan dan barat pantai yang lebih rendah, sering melimpah. Jenis serupa: Corallina elongata, sirip bercabang kontras dengan percabangan dikotomis dari Jania rubens. (lyer, 2004)

\section{Laurencia poitei Lamouroux}

Tanaman sekitar $10 \mathrm{~cm}$, tumbuh dalam kelompok padat. Bagian bawah tanaman yang halus, tapi ke arah ujung, cabang-cabang luar menanggung kecil, branchlets lemak yang dipotong atau kuadrat di ujungnya, tetapi tidak tuberculated. Tanaman pucat lebih dominan pada warna merah muda atau kecoklatan; konsistensinya sedikit tulang rawan. Habitat: Spesies ini mungkin sangat umum di perairan yang terlindung dan sering ditemukan seperti 'rol' di bagian bawah, membentuk gulungan, dengan diameter satu meter, yang bergerak melawan gelombang di daerah arus pasang surut (Gifford, 1853)

\section{Laurencia brongniartii J.Agardh}

Thalli ringan merah berwarna gelap, tegak, 8-15 cm, terdiri dari banyak tegak, dikompresi dengan kapak pipih yang timbul dari satu sampai beberapa pendek, batang silindris, 2-3 perintah cabang teratur dikotomis. Setiap beruang cabang menyirip, pendek, determinate, sebaliknya diatur branchlets, 3-6 mm. (John Huisman \& Cheryl Parker, 2011).

14. Dictyota dichotoma (Hudson) Lamouroux
Thallus coklat biasanya menengah, lebih gelap di dekat dasar, panjang 2$20 \mathrm{~cm}$, cukup teratur dichotomously bercabang pada interval $0.5-1(-3) \mathrm{cm}$, cabang (2 -) 3-7 (-10) mm luas (turun ke $1 \mathrm{~mm}$ dekat apeks intricata var.), biasanya lebih atau kurang linear dan meruncing hanya sedikit dari bawah ke bagian atas talus tersebut, jarang spiral memutar, axils lebih atau kurang bulat, apeks cabang bulat dan biasanya 3-4 mm yang luas tepat di bawah apeks (intricata invar sempit.), dengan spesimen sesekali meruncing di atas 0,5-1 cm untuk apiculate apices; proliferations biasanya tidak kecuali sebagai respon terhadap kerusakan, kadang-kadang hadir sedikit. Holdfast dari rhizoids; terutama epilithic. (John Huisman \& Cheryl Parker, 2011).

\section{Padina australis Hauck}

Bentuk thalli seperti kipas, membentuk segment-segment lembaran tipis (lobus) dengan garisgaris berambut radial dan perkapuran di bagian permukaan daun. Warna coklat kekuning-kuningan atau kadang-kadang memutih karena terdapat perkapuran. Holdfast berbentuk cakram kecil berserabut. Bagian atas lobus agak melebar dengan pinggir rata dan pada bagian puncak terdapat lekukan-lekukan yang pada ujungnya terdiri dari dua lapisan sel. Dalam padina, perbedaan bentuk lobus, garis rambut radial, ketebalan lembaran thallus dan kuantitas kalsifikasi (perkapuran) dijadikan identitas perbedaan jenisnya. Habitat alga ini menempel substrat berbatu pada kebanyakan lingkungan laut, terutama terumbu karang dangkal (Coremap, 2007). 
Tabel 1. Nilai Parameter Suhu, Salinitas, pH, Intensitas Cahaya dan Jenis Substrat di Pantai Pidakan Kabupaten Pacitan

\begin{tabular}{|c|c|c|c|c|c|c|c|c|c|c|c|c|c|c|c|}
\hline \multirow[t]{3}{*}{ Parameter } & \multicolumn{15}{|c|}{ Transek/Stasiun } \\
\hline & \multicolumn{3}{|c|}{ I } & \multicolumn{3}{|c|}{ II } & \multicolumn{3}{|c|}{ III } & \multicolumn{3}{|c|}{ IV } & \multicolumn{3}{|c|}{$\mathbf{V}$} \\
\hline & 1 & 2 & 3 & 1 & 2 & 3 & 1 & 2 & 3 & 1 & 2 & 3 & 1 & 2 & 3 \\
\hline Suhu $\left({ }^{\circ} \mathrm{C}\right)$ & 31 & 30 & 29 & 29 & 29 & 29 & 30 & 29 & 31 & 32 & 29 & 28 & 28 & 28 & 28 \\
\hline Nilai tengah & & 30 & & & 29 & & & 30 & & & 29,7 & & & 28 & \\
\hline $\begin{array}{l}\text { Salinitas } \\
\text { (\%o) }\end{array}$ & 35 & 34 & 35 & 35 & 35 & 34 & 34 & 34 & 35 & 33 & 35 & 35 & 36 & 35 & 35 \\
\hline Nilai tengah & & 34,7 & & & 34,7 & & & 34,3 & & & 34,3 & & & 35,3 & \\
\hline pH & 7,2 & 7,4 & 7,1 & 7,0 & 7,3 & 7,1 & 7,2 & 7,2 & 7,3 & 7,1 & 6,9 & 7,2 & 7,2 & 7,0 & 7,1 \\
\hline Nilai tengah & & 7,3 & & & 7,2 & & & 7,3 & & & 7,1 & & & 7,1 & \\
\hline Substrat* & 2 & 2 & 2 & 2 & 2 & 2 & 2 & 2 & 2 & 2 & 2 & 2 & 2 & 2 & 2 \\
\hline Nilai tengah & & 2 & & & 2 & & & 2 & & & 2 & & & 2 & \\
\hline $\begin{array}{l}\text { Intensitas } \\
\text { cahaya (lux) }\end{array}$ & 3890 & 4078 & 4745 & 4843 & 4890 & 4984 & 5362 & 5486 & 5376 & 5271 & 4587 & 4964 & 4875 & 4951 & 4853 \\
\hline Nilai tengah & & 4238 & & & 4906 & & & 5408 & & & 4940 & & & 4893 & \\
\hline
\end{tabular}

Keterangan $(*): 1=$ pasir, $2=$ batu karang, $3=$ lumpur

\section{PEMBAHASAN}

Pantai pidakan mempunyai tipe ekologi laut yang hampir sama dengan pantai-pantai di selatan Jawa identik dengan gelombang besar karena tergolong dalam lautan lepas Samudera Hindia, namun ada suatu perbedaan yang akan menjadi ciri khas pantai Pidakan dimana dari arah pantai menuju tubir terdiri dari zonasi batuan alam hampir $70 \%$ dan sisanya pasir putih, tumbuhan lamun, dan terumbu karang. Pantai pidakan masih tergolong asri (pristine condition) dengan ditandai tumbuhnya terumbu karang dekat kawasan pantai secara alami. Seluruh stasiun merupakan perairan pantai jernih, landai dan bersubstrat batuan karang dengan sedikit pasir yang terkadang ditumbuhi lamun. Karang tumbuh merata dengan paparan terumbu relatif luas dengan elevasi mendatar. Hal ini sesuai dengan pernyataan Nybakken (1998) bahwa daerah berkarang merupakan daerah yang mempunyai keragaman terbesar untuk spesies alga. Karena pada substrat ini alga dapat tumbuh dan menempel dengan baik. Menurut Ambas (2006) dasar perairan biasanya terkait dengan tingkat kecerahan perairan. Perairan dengan dasar karang atau karang mati biasanya memiliki kejernihan air yang relatif baik. Hal ini cukup penting bagi berlangsungnya fotosintesis alga. Sehingga, pada penelitian kali ini melakukan pengukuran suhu, salinitas, $\mathrm{pH}$, dan intensitas cahaya tanpa pengukuran tingkat kecerahan.

Hasil penelitian makroalga yang dilakukan di daerah pasang surut Pantai Pidakan Kabupaten Pacitan menunjukan bahwa daerah ini memiliki 15 jenis makroalga. Makrolaga yang ditemukan digolongkan dalam 3 divisi yaitu divisi Chlorophyta, Rhodophyta dan Phaeophyta. Hal ini sesuai dengan penelitian Palallo (2013) bahwa pada perairan Pulau Bonebatang terdiri dari 3 divisi yaitu Chlorophyta, Rhodophyta dan Phaeophyta.

Banyaknya jenis yang ditemukan tidak lepas dari kondisi lingkungan abiotik daerah pasang surut pantai Pidakan Kab. Pacitan yang meliputi suhu kisaran $28^{\circ} \mathrm{C}$ $30^{\circ} \mathrm{C}$, salinitas yang diukur berkisar $34-35$ \%o, pH berkisaran 7,1-7,3 yang menandakan keadaan netral sedikit basah, intensitas cahaya menunjukan kisaran 4000-5000 lux, dan tipe substrat berbatu dan berkarang. Sedangkan kisaran suhu, salinitas dan $\mathrm{pH}$ antara setiap lokasi penelitian atau stasiun tidak banyak bervariasi, mencerminkan kondisi umum perairan pantai tropis. Kondisi hidrologis tersebut memberikan kesempatan yang baik bagi kehidupan makroalga. Selain itu, tipe substrat batuan karang sangat cocok untuk pertumbuhan makroalga.

Adapun karakteristik populasi, indeks keanekaragaman jenis dan pola penyebaran makroalga di derah pasang 
surut Pantai Pidakan. Hasil analisi menunjukan bahwa kepadatan dan kepadatan relatif memiliki nilai yang bervariasi. Nilai kepadatan tertinggi didapatkan dari jenis Enteromorpha intestinalis yaitu $1,356 / \mathrm{m}^{2}(\mathrm{RD}=0,126)$, sedangkan kepadatan terendah adalah Caulerpa racemossa 0,178 $(\mathrm{RD}=0,017)$. Pada pengukuran nilai frekuensi dan frekeunsi relatif tertinggi didapatkan dari jenis Jania rubens yaitu 0,103 (RF = 0,103) dan frekeunsi terendah adalah Caulerpa racemossa dengan nilai 0,034 $(\mathrm{RF}=0,034)$. Hal ini berbeda dengan Papilia (2013) dipulau Ambalau Ambon frekuensi terbesar berasal dari jenis Caulerpa $(0,222)$ dan terendah diperoleh jenis Padina (0,175). Pada luas penutupan tertinggi dimiliki dari jenis Euchema edule yaitu $0,589(\mathrm{RC}=0,132)$ dengan luas penutupan terendah dari jenis Caulerpa racemossa $0,078(\mathrm{RC}=0,017)$.

Indeks nilai penting digunakan untuk mengetahui dominasi suatu jenis dalam komunitas. Berdasarkan hasil analisis didapatkan indeks nilai penting tertinggi pada jenis Euchema edule yaitu 0,301 dan indeks nilai penting terendah pada jenis Caulerpa racemossa hanya 0,068. Sedangkan pada penelitian Papilia (2013) dominasi tertinggi diperoleh Caulerpa sebesar 0,01 dan terendah diperoleh Padina sebesar 0,005.

Selanjutnya Nurmiyati (2013) pada pantai sepanjang Gunung Kidul mendapatkan Enteromorpha flexuosa memiliki nilai penting tertinggi yaitu 69.84 dengan nilai kepadatan relatif (RD $=30.98)$, luas tutupan relatif $(\mathrm{RC}=24.92)$ dan Frekuensi Relatif $(\mathrm{RF}=13.94)$. Nilai penting terendah adalah Caulerpa racemosa dari kelas Clorophyceae yaitu sebesar 1.08 dengan nilai kepadatan relatif $(\mathrm{RD}=0.05)$, luas tutupan relatif $(\mathrm{RC}=$ $0.21)$ dan frekuensi relatif $(F R=0.82)$.

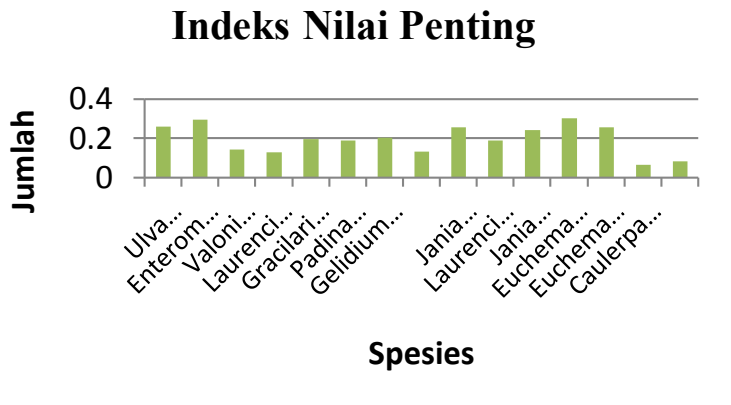

Ganmbar 1. Indeks Nilai Penting Makroalga

Euchema edule memiliki indeks nilai penting tertinggi dibandingkan jenis lainnya. Hal ini menunjukan bahwa populasi yang cukup banyak dan cukup mendominasi makroalga yang ada di daearah pasang surut pantai Pidakan Kabupaten Pacitan, sebab pada pengukuran kepadatan dan frekuensi yang tertinggi diperoleh dari jenis Enteromorpha intestinalis dan Jania rubens bukan berasal dari Euchema edule. Hasil ini berpengaruh pada indeks keragaman dimana kepadatan jenis-jenis yang relatif berimbang dari anggota komunitas lainnya menyebabkan indeks keragaman Shannon-Wiener $\left(\mathrm{H}^{\prime}\right)$ pada kategori tinggi yaitu 4,611 (H>4) .

Namun demikian secara kuantitatif dapat dikatakan bahwa pada komunitas makroalga tersebut tidak terdapat dominasi satu jenis. Ini dapat dilihat dari indeks kemerataan atau evenness (E) yang cukup tinggi yaitu 0,609 , karena mendekati nilai kemerataan yang sedang $(0,4<\mathrm{E}<0,6)$. Hal ini menunjukkan bahwa sebaran kuantitatif nilai kepadatan antara anggota komunitas cenderung merata (E mendekati 1). Sedangkan penelitian Palallo (2013) di kepulauan Bonebatang nilai keragaman (H') lebih kecil di bandingkan dengan pantai Pidakan sebab dikategoikan rendah yaitu berkisar 1,31-1,70 serta nilai keseragaman (E) berkisar 0,58-0,66 temasuk tingkat kemerataan yang sedang.

Tabel 2. Indeks Keanekaragaman Makroalga

\begin{tabular}{clcl}
\hline No & Parameter & Nilai & Keterangan \\
\hline $\mathbf{1}$ & Shannon-Wiener (H') & 4,611 & $\begin{array}{l}\text { Keragaman jenis } \\
\text { sangat tinggi }\end{array}$ \\
$\mathbf{2}$ & Evenness (E) & 0,609 & $\begin{array}{l}\text { Kemerataan jenis } \\
\text { tinggi }\end{array}$ \\
\hline
\end{tabular}


Hasil analisis pola penyebaran ditampilkan pada Tabel 3. Bila didasarkan pada klasifikasi Indeks Morisita (dalam Yusron, 2001) yaitu $=1$ (pola penyebaran acak/random), nilai $<1$ (pola penyebaran merata/uniform), dan $>1$ (pola penyebaran berkelompok/clumped), maka pola penyebaran semua jenis makroalga yang ditemukan dalam penelitian di daerah pasang surut panti Pidakan Kabupaten Pacitan adalah berkelompok (IM > 1). Sedangkan Rochmah (2003) pada pantai Panjang Bengkulu hanya 1 jenis yang memiliki pola penyebaran berkelompok, hal ini disebabkan keadaan pantai yang mulai tercemar berbeda dengan pantai Pidakan Pacitan yang masih alami.

Tabel 3. Pola Penyebaran Jenis Makroalga

\begin{tabular}{|c|c|c|c|c|c|}
\hline Jenis & $\mathbf{n}$ & $\mathbf{N}$ & $\sum \mathbf{X}^{2}$ & IM & Ket. \\
\hline Ulva lactuca & 15 & 164 & 7914 & 4,35 & Clumped \\
\hline $\begin{array}{l}\text { Enteromorpha } \\
\text { intestinalis }\end{array}$ & 15 & 244 & 24152 & 6,05 & Clumped \\
\hline $\begin{array}{l}\text { Valoni } \\
\text { aegagropila }\end{array}$ & 15 & 121 & 6985 & 7,1 & Clumped \\
\hline $\begin{array}{l}\text { Laurencia } \\
\text { poitei }\end{array}$ & 15 & 112 & 5838 & 6,9 & Clumped \\
\hline $\begin{array}{l}\text { Gracilaria } \\
\text { gracilis }\end{array}$ & 15 & 129 & 3495 & 3,05 & Clumped \\
\hline $\begin{array}{l}\text { Padina } \\
\text { Australis }\end{array}$ & 15 & 117 & 4173 & 4,48 & Clumped \\
\hline $\begin{array}{l}\text { Gelidium } \\
\text { amansii }\end{array}$ & 15 & 136 & 4072 & 3,21 & Clumped \\
\hline $\begin{array}{l}\text { Dictyota } \\
\text { dichotoma }\end{array}$ & 15 & 95 & 2181 & 3,5 & Clumped \\
\hline Jania rubens & 15 & 138 & 4926 & 3,8 & Clumped \\
\hline $\begin{array}{l}\text { Laurencia } \\
\text { brongniartii }\end{array}$ & 15 & 109 & 3021 & 3,71 & Clumped \\
\hline $\begin{array}{l}\text { Jania } \\
\text { longifurca }\end{array}$ & 15 & 146 & 7388 & 5,13 & Clumped \\
\hline Euchema edule & 15 & 166 & 7570 & 4,05 & Clumped \\
\hline $\begin{array}{l}\text { Euchema } \\
\text { cottoni }\end{array}$ & 15 & 164 & 7970 & 4,38 & Clumped \\
\hline $\begin{array}{l}\text { Caulerpa } \\
\text { racemossa }\end{array}$ & 15 & 32 & 304 & 4,11 & Clumped \\
\hline Codium edule & 15 & 52 & 758 & 3,99 & Clumped \\
\hline
\end{tabular}

Berdasarkan Uji Kelayakan Handout Biologi Makroalga dengan menggunakan metode angket yang dilaksanakan di MAN Gondanglegi kepada guru mata pelajaran Biologi Ibu Dra. Siti Mutmainah dan SMAN 2 Batu oleh Ibu Feni Tin F., Spd menghasilkan nilai di atas $89 \%$ dan $62 \%$ maka dapat disimpulkan bahwa uji kelayakan handout Biologi Makroalga ini berhasil atau layak digunakan dalam pembelajaran dengan perbaikan yang dilakukan berdasarkan beberapa catatan saran/komentar.

\section{KESIMPULAN DAN SARAN}

\section{Kesimpulan}

Identifikasi yang ditemukan sebanyak 15 spesies, dengan deskripsi bentuk morfologi tiap spesies alga makro yang ditemukan berbeda satu dengan yang lainnya. Untuk substrat ternyata hanya 2 tipe yakni berkarang dan berpasir. Faktor abiotik pantai Pidakan sangat mendukung untuk pertumbuhan alga makro dengan diketahuinya nilai Indeks Morisita (IM) berkisar antara 3,05 sampai dengan 7,1 atau nilai $\mathrm{IM}>1$ yang berarti pola penyebaran semua jenis makroalga di daeraah Pasang Surut Pantai Pidakan Kabupaten Pacitan adalah berkelompok (clumped). Disaming itu, Hasil Identifikasi Keanekaragaman pada darah pasang surut pantai Pidakan dapat digunakan sebagai sumber belajar biologi yang berupa Handout Makroalga tingakt SMA/MA kelas $\mathrm{X}$ semester 1 pada materi Protista mirip tumbuhan.

\section{Saran}

Makroalga yang terdapat di daerah pasang surut pantai Pidakan Kabupaten Pacitan merupakan sumberdaya yang sangat besar dan sangat potensial dengan kepadatan berkisar antara $0,178 / \mathrm{m}^{2}$ $1,356 / \mathrm{m}^{2}$. Hal ini dapat menjadi acuan bagi masyarakat untuk membentuk kelompok tani rumput laut atau membangun usaha dalam bidang pembudidayaan rumput laut (makroalga). Kedua, Hasil penelitian ini dapat dijadikan sebagai acuan dasar bagi penelitian lanjut khususnya yang terkait dengan kelompok protista mirip tumbuhan seperti halnya Mikroalga di Kabupaten Pacitan sebagai sumber belajar biologi, mengingat materi protista mirip tumbuhan terdiri dari mikroalga dan makroalga. 


\section{DAFTAR PUSTAKA}

Afriyani, Erma. 2005. Upaya Mengoptimalkan Pemahaman Konsep Ekosistem Siswa Kelas VII SMP 1 Aluh-Aluh Kabupaten Banjar Tahun Pelajaran 2004/2005 dengan Menggunakan Pendekatan Lingkungan. Skripsi. Program Sarjana S-1 Biologi FKIP UNLAM, Banjarmasin. (tidak dipublikasikan).

Asyhar, Rayandra. 2010. Kreatif Mengebangkan Media Pendidikan. Jakarta: Gaung Persada Press.

Ambas, Irfan. 2006. Pelatihan Budidaya Laut (Coremap Fase II Kab. Selayar). Makasar: Yayasan Mattirotasi. Available from: www.google.com. Diakses pada tanggal 23 November 2009

Coremap,2007. Deskripsi Alga hijau, merah dan coklat. Online. http://www. coremap.or.id. Diakses 18 Mei 2014

Gifford, Isabella. 1853. The Marine Botanist An Introduction; To The Study Of The British Sea-Weeds; Description Of All The Species, And The Best Method Of Preserving Them. Thrid Edition. Brighton : R. Folthorp, 170 North-Street Longman And Co London.

Harvey, Willian Henry. 1853. A Manual British Marine Algae. London : John Van Voorst, Paternoster Row. M.DCCC.XLIX

Iyer, R .et all. 2004 . Morphological And taxonomy Studies Of Gracilaria and Gracilariopsis Species (Gracilariales, Rhodophyta) From South Africa. South Africa Jurnal of Botany 2004 ISSN, 70(4) : 521-539.

John Huisman \& Cheryl Parker. 2011. Deskripction Dictyota dichotoma Brown Algae . Online. http://florabase.dpaw.wa.gov.au. Diakses 12 Juni 2014

Kadi, \& Atmajaya, W. S., 1988. Rumput Laut (Alga), Jenis, Reproduksi,
Produksi, Budidaya dan Pasca Panen. LIPI. Jakarta.

McHugh DJ. 2003. A Guide To The Seaweed Industry. Online : www.fao.org/seaweed. Diakses 08 Juni 2014

Nurmiyati . 2013. Keragaman, Distribusi dan Nilai Penting Makro Alga Di Pantai Sepanjang Gunung Kidul. Jurnal ISSN 1693-2654. Prodi Pendidikan Biologi FKIP UNS Suakarta. Vol.6 No. 1 Hal. 12-21.

Nybakken.1992. Biologi Laut Suatu Pendekatan Ekologis. Jakarta : Gramedia Pustaka Utama

Pacitankab. 2007. Profil Kabupaten Pacitan. (online. www.pacitankab.go.id/monografi.ph p) Diakses 26 Februari 2014

Pallalo. 2013. Distribusi Makroalga Pada Ekosistem Lamun Dan Terumbu Karang Di Pulau Nonebatang, Kecamatan Ujung Tanah, Kelurahan Barrang Lompo, Makassar. Skrispsi Kelautan. UNHAS Makassar.

Papilia. 2013. Produktivitas Biomassa Makroalga Di Perairan Pulau Ambalau, Kabupaten Buru Selatan. Jurnal Ilmu dan Teknologi Kelautan Tropis, Vol. 5, No. 2, Hal.465-477

Rochmah. 2003. Keanekaragaman, Kepadatan, dan Pola Penyebaran Makroalga di Pantai Panjang Kota Bengkulu. Makalah Seminar dan Rapat Tahunan Bidang MIPA. Universitas Sriwijaya

Setchel \& Gardener. 1920. The Marine Algae Of The Pacific Coast Of North America Part II Chlorophyceae. University Of Calaifornia Puclications In Botany. Vol.8, No.2, pp.139-374, plates 9-33.

1925. The Marine Algae Of The Pacific Coast Of North America Part III Melanophyceae. University Of Calaifornia Puclications In Botany. Vol.8, Part III, pp.383-898, plates 34-107.

Sulistijo.2009. Buku Modul Rumput Laut (Makroalga). Jakarta: Pusat 
Penelitian Oceanografi Lembaga Ilmu Pengetahuan Indonesia.

Yusron, Eddy. 2001. Struktur Komunitas Teripang (Holothuroidea) di Rataan Terumbu Karang Perairan Pantai
Morella Ambon. Pesisir dan Pantai Indonesia IV. Pusat Penelitian dan Pengembangan Oseanologi-LIPI. Jakarta. Hal. 227-233. 